\title{
Peranan Badan Usaha Milik Desa Menurut Undang-Undang Nomor 6 Tahun 2014 Tentang Desa dalam Meningkatkan Pendapatan Asli Desa
}

\author{
Junaidi $^{1 * *}$, Amri Amir ${ }^{2}$, Amril $^{3}$, Adi Bhakti ${ }^{4}$, Eko Prasetyo ${ }^{5}$ \\ 1,2,3,4,5) Fakultas Ekonomi dan Bisnis, Universitas Jambi, Jl. Raya Jambi - Muara Bulian KM. 15, \\ Muaro Jambi, Jambi
}

Diterima: 12-07-2021

Direvisi: 20-07-2021

Disetujui: 25-07-2021

Dipublikasi: 18-08-202

\begin{abstract}
The purpose of this service activity is to socialize the role of Village-Owned Enterprises in order to increase village original income. The activity was carried out in Pemayung District, Batanghari Regency, followed by 24 village officials and BUMDes managers. The material provided includes Law Number 6 of 2014 concerning Villages and Village-Owned Enterprises.
\end{abstract}

Keywords: BUMDes, PADes, villages

\begin{abstract}
Abstrak
Tujuan dari kegatan pengabdian ini adalah untuk mensosialisasikan peranan Badan Usaha Milik Desa dalam rangka meningkatkan pendapatan asli desa. Kegiatan dilaksanakan di Kecamatan Pemayung Kabupaten Batanghari, diikuti oleh 24 perangkat desa dan pengelola BUMDes. Materi yang diberikan mencakup Undang-Undang Nomor 6 Tahun 2014 tentang Desa dan Badan Usaha Milik Desa.
\end{abstract}

Kata kunci: BUMDes, PADes, desa

\section{Pendahuluan}

Badan Usaha Milik Desa (BUMDes) merupakan lembaga/badan perekonomian desa yang berbadan hukum. BUMDes dibentuk dan dimiliki oleh Pemerintah Desa, dikelola secara ekonomis mandiri dan profesional. Modal BUMDes berasalah dari kekayaan desa yang dipisahkan, baik secara keseluruhan atau sebagian besarnya. Tujuan pembentukan BUMDes adalah untuk memperoleh keuntungan dan sumber Pendapatan Asli Desa (PADes), sekaligus untuk meningkatkan perekonomian desa, serta kesejahteraan masyarakatnya (Ridlwan, 2013).

BUMDes memiliki peran yang strategis karena dapat menjadi penggerak perekonomian desa dan kesejahteraan masyarakat desa. Melalui BUMDes diharapkan terbentuknya usaha baru yang berakar dari sumber daya yang ada serta optimalisasi kegiatankegiatan ekonomi masyarakat desa yang telah ada. Selanjutnya melalui BUMDes juga diharapkan akan terjadi peningkatan kesempatan berusaha dalam rangka memperkuat otonomi desa dan mengurangi pengangguran. Menurut Prabowo (2014) dan Ansari (2016) salah satu upaya dalam mendorong pertumbuhan ekonomi desa adalah melalui kewirausahaan desa. Kewirausahaan desa ini sendiri dapat diwadahi dalam BUMDes.

Pengaturan BUMDes diatur di dalam Undang- undang Desa nomor 6 Tahun 2014 tentang Desa, yang menyatakan bahwa Desa dapat mendirikan BUMDes sesuai dengan kebutuhan dan potensi desa. BUMDes bertujuan agar aset-aset desa dapat dikelola secara

\footnotetext{
*Penulis korespondensi

Email: junaidi@unja.ac.id
} 
optimal. Pada tahap selanjutnya, hal ini akan berdampak pada kemajuan perekonomian desa, serta kesejahteraan masyarakatnya.

BUMDes adalah usaha dengan orientasi keuntungan, yang dikelola dengan prinsip keterbukaan, kejujuran, partisipasif dan berkeadilan. Oleh karenanya, dengan terbentuknya BUMDes, desa-desa akan menjadi lebih mandiri serta masyarakat desa akan lebih sejahtera.

Mengingat BUMDes adalah konsep baru, dalam prakteknya terdapat berbagai kendala terutama dalam proses pembentukannya. Pertama, belum tersedianya payung hukum keberadaan BUMDes di desa. Kedua, masih terdapatnya kerancuan terkait dengan legalitas bentuk badan hukum pendirian BUMDes.

Pada dasarnya beberapa daerah telah memiliki Perda tentang tata cara pembentukan dan pengelolaan BUMDes. Namun demikian, seringkali Perda-Perda tersebut kurang tepat dalam memilih konstruksi badan hukum untuk BUMDes. Bahkan terdapat Perda yang tidak menggunakan bentuk badan hukum, melainkan hanya berbentuk badan usaha yang tidak berbadan hukum untuk BUMDes. Hal ini tidak sesuai dengan ketentuan pasal 78 ayat (3) Peraturan Pemerintah Nomor 72 Tahun 2005 tentang Desa yang menyatakan bentuk BUMDes harus berbadan hukum

Permasalahan terkait dengan BUMDes ini juga terjadi dan berlaku umum di desa-desa di Provinsi Jambi. Oleh karenanya diperlukan sosialiasi yang intensif pada pemerintahan desa agar pembentukan dan pengelolaan BUMDes dapat berjalan baik dan mampu memperkuat PADes khususnya dan meningkatkan kesejahteraan masyarakat pada umumnya.

Kegiatan pengabdian masyarakat ini dilaksanakan di Kecamatan Pemayung Kabupaten Batanghari Provinsi Jambi. Pemilihan lokasi ini didasarkan pertimbangan masih relatif sedikitnya BUMDes yang ada di desa-desa di lingkungan Kecamatan Pemayung ini.

\section{Metode}

Tahap kegiatan pengabdian kepada masyarakat ini diawali dengan tahap perencanaan. Pada tahap perencanaan, tim pengabdian mendiskusikan tema kegiatan dan survey awal. Berdasarkan hasil survey awal ditetapkan lokasi kegiatan adalah desa-desa yang ada di lingkungan Kecamatan Pemayung Kabupaten Batang Hari.

Tahap berikutnya adalah melakukan pendekatan dengan Camat Kecamatan Pemayung untuk mendapatkan izin penyelenggaran dan penetapan jadwal kegiatan. Setelah mendapatkan izin dan tanggal kegiatan, tim menyusun materi pengabdian yang akan disampaikan.

Pelaksanaan kegiatan menggunakan beberapa metode yaitu metode ceramah, simulasi dan diskusi. Setelah pelaksanaan kegiatan, dilakukakan tahapan evaluasi. Evaluasi bertujuan untuk melihat serapan peserta terhadap materi yang disampaikan serta harapan peserta terhadap keberlanjutan kegiatan ini.

\section{Hasil dan Pembahasan}

Salah satu kelemahan pembangunan desa adalah keterbatasan dalam sumber pendanaan pembangunan. Oleh karenanya pemerintah telah melakukan berbagai upaya kebijakan dalam pendanaan desa ini. Salah satunya adalah melalui BUMDes (Prasetyo, 2016).

Dalam pasal 87 ayat 1 UU Nomor 6 Tahun 2014 Tentang Desa dinyatakan desa dapat mendirikan badan usaha milik desa yang disebut BUMDes. Peraturan tentang desa ini menunjukkan suatu bentuk pengakuan dan penghormatan terhadap prakarsa desa dalam gerakan usaha ekonomi. Interpretasi sistem hukum terhadap peraturan perundang-undangan 
tentang desa menghasilkan peta jalan pendirian BUMDes. Pendirian BUMDes didasarkan atas prakarsa Desa yang mempertimbangkan:

a) Inisiatif Pemerintah Desa dan atau Masyarakat Desa

b) Potensi usaha ekonomi desa

c) Sumber daya alam didesa

d) Sumber daya yang mengelola BUMDes

e) Penyertaan modal dari Pemerintah Desa dalam bentuk pembiayaan dn kekayaan Desa diserahkan untuk dikelola sebagai bagain dari BUMDes.

Pendirian BUMDes hendaklah disepakati melalui Musyawarah Desa, atau dengan nama lain adalah Musyawarah antara Badan Permusyawaratan Desa, Pemerintah Desa dan unsur masyarakat yang diselenggarakan oleh Badan Permusyawaratan Desa untuk menyepakati hal-hal yang bersifat strategis.

Keputusan dari Musyawarah desa dituangkan dalam berita acara yang ditandatangani oleh Ketua Badan Permusyawaratan desa dan kepala Desa. Pokok bahasan yang dibicarakan dalam musyawarah desa meliputi hal-hal sebagai berikut:

a) Pendirian BUMDes sesuai dengan kondisi sosial ekonomi masyarakat

b) Organisasi pengelola BUMDes

c) Modal usaha BUMDes

d) Anggaran dasar dan anggaran rumah tangga BUMDes

Pendirian BUMDes memerlukan langkah-langkah kelembagaan BUMDes secara partisipatif. Tujuannya, agenda pendirian BUMDes benar-benar dengan denyut nadi usaha ekonomi desa dan demokritasiasi desa. Menurut Anom (2015), langkah-langkah yang harus diambil adalah a) Sosialisasi tentang BUMDes dan b) Pelaksanaan musyawarah desa.

Kegiatan pengabdian kepada masyarakat ini telah dilaksanakan di di Aula Kantor Camat Pemayung Kabupaten Batang Hari yang diikuti oleh 24 Perangkat Desa dan Pengelola BUMDes. Materi yang diberikan mencakup:

a) Pembentukan dan atau pendirian BUMDes di desa yang ada dalam wilayah Kecamatan Pemayung Kabupaten Batang Hari.

b) Pelatihan dalam pengelolaan BUMDes, bagi desa yang telah terbentuk desa yang ada dalam wilayah Kecamatan Pemayung Kabupaten Batang Hari.

c) Strategi BUMDes dalam peningkatan Pendapatan Asli Desa

Setelah pemberian materi baik dengan metode ceramah maupun simulasi, dilanjutkan dengan sesi diskusi dan tanya jawab. Pada sesi ini juga sekaligus dilakukan evaluasi terhadap pelaksanaan kegiatan.

Respon peserta terkait dengan kegiatan ini sangat baik. Banyak peserta yang mengajukan pertanyaan dan tanggapan terkait materi yang disampaikan. Pada sesi diskusi terungkap bahwa desa-desa di Kecamatan Pemayung memiliki potensi untuk mendirikan BUMDes. Berbagai jenis usaha yang potensial untuk dikembangkan diantaranya adalah usaha jasa seperti jasa keuangan mikro dan jasa komunikasi, usaha penyaluran sembilan bahan pokok, usaha perdagangan hasil pertanian dan usaha industri kecil dan rumah tangga.

Dalam pengembangan BUMDes ini juga disarankan dua alternatif. Pertama, masingmasing desa dapat membentuk BUMDes dengan usaha desa sendiri, dan kedua, pembentukan BUMDes dengan melakukan kerjasama usaha antara dua desa atau lebih.

Pada akhir sesi diskusi, peserta mengharapkan adanya tindak lanjut dari kegiatan ini. Ada dua aspek tindak lanjut yang diharapkan peserta. Pertama adalah, pendampingan kepada pengelola BUMDes dalam manajemen dan pengelolaan usaha serta kedua pendampingan kepada aparat desa terkait dengan penyusunan peraturan desa untuk pembentukan BUMDes. 


\section{Kesimpulan dan Saran}

\section{Kesimpulan}

Badan Usaha Milik Desa (BUMDes) memiliki peran yang potensial dalam meningkatkan Pendapatan Asli Desa. Namun demikian, saat ini masih banyak desa yang belum membentuk BUMDes. Persoalan yang mendasar adalah masih rendahnya pemahaman masyarakat dan aparat desa terkait pembentukan dan pengelolaan BUMDes.

Kegiatan pengabdian kepada masyarakat ini yang dilaksanakan dalam bentuk penyuluhan telah dapat memberikan pemahaman terkait dengan pembentukan BUMDes dan pengelolaannya. Oleh karenanya, diharapkan kegiatan ini akan dapat mendorong terbentuknya BUMDes di desa-desa khususnya di desa-desa di lingkungan Kecamatan Pemayung.

\section{Saran}

Sebagai tindak lanjut dari kegiatan ini, perlu dilakukan pendampingan pada dua pihak. Pendampingan manajemen dan pengelolaan usaha pada pengelola BUMDes serta pendampingan pada aparat desa dalam penyusunan peraturan pembentukan BUMDes.

\section{Daftar Pustaka}

Anom, S.P. (2015). Buku 7 Badan Usaha Milik Desa: Spirit Usaha Kolektif Desa. Kementerian Desa, Pembangunan Daerah Tertinggal dan Transmigrasi

Ansari, B., Mirdamadi, S.Y., Zand, A. \& Arfaee, M.. (2013). Sustainable Entrepreneurship in Rural Areas. Research Journal of Environmental and Earth Science, 5(1), 26-31.

Pemerintah Indonesia. (2014). Peraturan Menteri Dalam Negeri Nomor 113 Tahun 2014 tentang Pedoman Pengelolaan Keuangan Desa.Sekretariat Negara

Pemerintah Indonesia. (2014). Undang-undang Desa nomor 6 tahun 2014 tentang desa. Sekretariat Negara

Prabowo, T.H.E. (2014). Developing BUMDes (Village-owned Enterprise) for Sustainable Poverty Alleviation Model Village Community Study in Bleberan-Gunung Kidul Indonesia. World Applied Sciences Journal, 30, 19-26

Prasetyo, R.A. (2016). Peranan BUMdes dalam Pembangunan dan Pemberdayaan Masyarakat di Desa Pejambon Kecamatan Sumberrejo Kabupaten Bojonegoro. Jurnal Dialektika, 11(1), 86-100

Ridlwan, Z. (2013). Payung Hukum Pembentukan BUMDes. Fiat Justisia: Jurnal Ilmu Hukum, 7(3), 355-370. https://doi.org/10.25041/fiatjustisia.v7no3.396. 